\title{
Comparison of the effect of natural and commercial honey on the growth and Antibiotic sensitivity of Escherichia coli and Pseudomonas aeruginosa
}

\author{
Shaimaa Abd Mohammed Ali \\ University of Tikrit - College of Agriculture - Department of Food Science \\ Correspondence author: Sheimaa.abed@yahoo.com
}

\begin{abstract}
This study was conducted to evaluate the inhibitory activity of two types of natural honey ( citrus flowers honey and eucalyptus honey) and two types of commercial honey available in the market (sinbola honey and shafi honey), on growth of Escherichia coli, Pseudomonas aeruginosa. and their sensitivity to antibiotics Amikacine

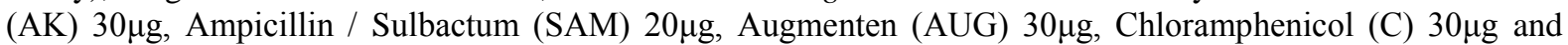
Gentamicin (GM) $10 \mu \mathrm{g}$. The results showed that the natural honey significantly superiority compared to commercial honey on inhibiting bacterial growth for isolates. The diameter of inhibition zone of citrus flowers honey and eucalyptus honey against $E$. coli growth was 20 and $21 \mathrm{~mm}$, respectively and $P$. aeruginosa was 19 and $14 \mathrm{~mm}$, respectively compared to commercial sinbola honey which gave an inhibition diameter of $E$. coli 8 $\mathrm{mm}$ while not affected on P. aeruginosa, as for shafy honey it not affected in bacterial isolates growth. Also the results showed that the citrus flowers honey exceeded significantly compared to eucalyptus honey for $P$. aeruginosa the inhibition diameters of citrus flowers honey and eucalyptus honey were 19 and $14 \mathrm{~mm}$ respectively. On the other hand, the results showed that the inhibitory effect of natural honey was closely related to antibiotics, and it gave a positive result when compared to the standard tables of the inhibition of antibiotics. $P$. aeruginosa was resistant to both chloramphenicol, Augmenten and Ampicillin, while sensitive for two types of natural honey. The results indicated that the combination of natural and commercial honey with antibiotics was increased the efficiency of antimicrobial activity of antibiotics by increasing the diameters of bacterial growth inhibition compared with the diameters which given by antibiotics. The citrus flower honey had the greatest inhibitory effect on bacterial isolates when it was mixed with antibiotics followed by Eucalyptus honey, while commercial sinbola honey was the least impact.
\end{abstract}

Key words: Honey, antibiotics, Escherichia coli, Pseudomonas aeruginosa

\section{Introduction}

The excessive use of drugs led to the emergence of resistant bacterial isolates to antibiotics as well as harmful side effects as chemicals or chemical substances, which made scientists and researchers are turning to the use of natural materials, especially honey as an alternative to medicines or supplement to reduce the dose of medicines. The oldest use of honey in the cleansing and healing of wounds, and the history of the use of honey is back to $2000-2100$ BC. is characterized by being widespread in most cities of the world, if not all (1).

Honey has an antimicrobial effect against many species of bacteria (both positive and negative), as well as viruses and fungi, this is due to the composition of it which contains a number of different component (2) include phenolic acids and hydrogen peroxide, as well as the osmotic effect of honey caused by its sugary components (1) and (3) in addition to low acidity ranging from 3.6 to 4.0 and the high honey viscosity prevents penetration of bacteria and formation of colonies (4).

Honey has an antibiotic effect on bacterial species that have the ability to form biofilm especially $P$. aeruginosa which cause many diseases such as sinusitis, wound inflammation and burns, and other Gram-negative species as aquired Hospitalized diseases (5), it has become multidrug resistant because of their biofilm composition, which does not allow the antibiotics penetration that used in treatment, but when shed honey on these types of bacteria found that it is more effective than antibiotics in killing these bacteria.(6), (7) and (8).

The honey consists of $38 \%$ fructose, $31 \%$ glucose, $10 \%$ other sugars, $17 \%$ water and a high percentage of nutrients, amino acids, vitamins and minerals as well as some enzymes added by bees during the manufacture and the enzyme Invertase, which converts sucrose to glucose and fructose therefore the content of the honey is only $1 \%$ sucrose (9). our prophet Mohammed (peace be upon him) said: "Healing in three honey drink, cupping and burning with fire but I do not recommend fire.

As a result of the resistance mechanisms development of microbes against many antibiotics, we considered this study, which aims to use honey as an alternative antibiotic, increase the efficiency of antibiotics and make a comparison in the inhibitory effect between natural honey and commercial honey against bacterial growth.

Materials and methods:

- Types of honey: 
Four types of honey were used, two types of natural honey (Citrus flower honey, eucalyptus and clover honey) and two types of commercial honey were available in the market as ( Sinbola and Shafi)..

\author{
Antibiotics discs: - \\ 1- Amikacine (AK) $30 \mu \mathrm{g}$

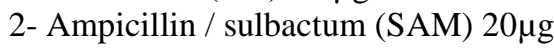 \\ 3- Augmenten( Amoxillin /clavulanic acid) $30 \mu \mathrm{g}$ \\ 4 Chloramphenicol (C) $30 \mu \mathrm{g}$ \\ 5- Gentamicin (GM)10 $\mu$
}

\section{- Culture media \\ 1- nutrient agar \\ 2- macConkey agar \\ 3- muller hinton agar}

\section{Bacterial isolates -}

Two isolates were taken from Microbiology Laboratory at the college of Science / University of Tikrit isolated from urinary tract infections and intestinal inflammation and were confirmed to return to Pseudomonas aeruginosa and Escherichia coli following a number of tests involving growth on the MacConkey Agar, gram stain, as well as a number of chemical tests, such as the indole test, the methyl red test and the citrate utilization test (10) and reactivated on nutrient agar medium then incubated at $37^{\circ} \mathrm{C}(11)$.

\section{- Antibiotic sensitivity test:}

The sensitivity test for a number of antibiotics was conducted by using the Kirby-baure method as described by (12). A suspension of bacterial isolates was carried out by transferring a number of pure colonies to tubes containing the nutrient broth and incubated in $37^{\circ} \mathrm{C}$ for $18-24$ hours and then compared with macfarl and standared Solution which is equal $1.5 \times 10^{8} \mathrm{cell} / \mathrm{ml}$ (13). In the case of unequal tubes turbidity, the normal slain solution add until the turbidity is equal to the mcfarl and tube, the sterile cotton swab is submerged in the growth and spread on the culture media surface and left to dry for 15 minutes and then distributed the antibiotic discs by sterile forceps and incubated dishes at $37^{\circ} \mathrm{C}$ for $18-24$ hours, after which the diameters of the inhibition area were measured for each disk and compared with the standard tables of the WHO.

\section{Effect of honey on bacterial growth:-}

The sensitivity test was conducted by using disc diffusion method according to the method described by (14). Prepare the discs of the filter paper saturated with each type of honey under study after confirmation of honey from microbes by filtering in special filters, bacterial inoculums for each of $E$. coli, $P$. aeruginosa, were transfer by sterile cotton swab to the surface of the muller hinton agar after comparing it with the mcfarl and tube. The honey-saturated discs were then placed on the surface of the cultivated dishes and incubated at $37^{\circ} \mathrm{C}$ for $18-24$ hours and diameter of inhibition zones were measured by millimeters.

\section{- The sensitivity test of bacterial growth affected by combination of honey with some antibiotics:}

The bacterial inoculums was transferred from each of bacterial isolates studied by sterile cotton swab to the muller hinton surface by using disc diffusion method, these antibiotic discs for the five studied species after they were saturated with $50 \mu \mathrm{l}$ of each of the four honey types were placed on the surface of the cultivated dishes and incubated at $\left(37^{\circ} \mathrm{c}\right)$ for the period (18-24) hours after which the regions of the inhibition zones were measured for each disc by millimeters (12).

\section{Statistical analysis}

The experiment was statistically analyzed using ANOVA, and the averages was compared with Duncans values at the level of 0.05 based on the program (15).

\section{Results and discussion:}

Data in table (1) shows the sensitivity of bacterial isolates to some antibiotics. The table shows that $P$. aeruginosa resistant to Ampicillin , Amoxillin and clavulanic acid (Augmenten) while, E. coli was sensitive to Ampicillin, the bacteria resistance to these antibiotics due to its possession $\beta$-lactamase enzymes, which altered the structure of the antibiotic by breaking the beta-lactam ring(16). The results show that all bacterial isolates were sensitive to Amikacine and Gentamicin. As for chloramphenicol, the bacterial isolates showed resistance to them. The causes of bacterial resistance to antibiotics are due to several factors including the modulation of the target site of antibiotic binding (17), as well as the possession of bacteria to the active stream mechanism which reduces the antibiotic accumulation within the bacterial cell (18).

Table 1. Bacterial isolates Sensitivity to certain some antibiotics (inhibition zone by $\mathrm{mm}$ )

\begin{tabular}{llllll}
\hline \multirow{2}{*}{ Bacterial isolates } & \multicolumn{7}{c}{ Antibiotics } \\
\cline { 2 - 6 } & $\mathrm{C}$ & AK & GM & AUG & SAM \\
\hline E.coli & $18(\mathrm{R})$ & $21(\mathrm{~S})$ & $19(\mathrm{~S})$ & $18(\mathrm{R})$ & $17(\mathrm{~S})$ \\
\hline P.aeruginosa & $0(\mathrm{R})$ & $26(\mathrm{~S})$ & $23(\mathrm{~S})$ & $0(\mathrm{R})$ & 0 \\
\hline S: Sensetive & R: Resistance & & & \\
C: Chloramphenicol & AK: Amikacine & GM: Gintamicin & & \\
AUG: Augmenten (Amoxillin / Clavulanic acid) & SAM: Ampicillin / Sulbactam & &
\end{tabular}


Data in table 2 shows the sensitivity of bacterial isolates to the natural and commercial honey species. Two types of natural honey were used: (citrus flowers honey and eucalyptus honey) as well as two types of commercial honey available in the market (sinbola honey and shafi honey). The results show that natural honey achieved significant superiority on commercial honey in inhibiting bacterial growth for all bacterial isolates, the diameter of inhibition of citrus flower honey and eucalyptus honey of the E.coli growth 20, $21 \mathrm{~mm}$ respectively and $19 \mathrm{~mm}, 14 \mathrm{~mm}$ respectively for $P$. aeruginosa compared to commercial honey sinbola which gave an inhibition diameter of E. coli 8 $\mathrm{mm}$ while not affected in $P$. aeruginosa. These results may be due to the difference in the sources of the bees feeding in being sources abnormal for honey commercial as a sugar and water. This is agreed with the findings of (19) and (20) who found that the natural honey superiority on commercial honey . As for the two types of natural honey, the results show that the citrus flower honey exceeded significantly on eucalyptus honey for $P$. aeruginosa were $19 \mathrm{~mm}$ and $14 \mathrm{~mm}$, as for $E$. coli there was no significant difference between the two types of natural honey, these results are in agreement with those obtained by Alqurashi et al.(21). When we observed the inhibitory effect of natural honey is closely related to antibiotics (Table, 1), and it gave a positive result when compared with the standard tables of the diameters of inhibition of antibiotics. P. aeruginosa was resistant to chloramphenicol, Augmenten and Ampicillin, while sensitive for two types of natural honey as shown in Table (2). The diameter of the inhibition area is $19 \mathrm{~mm}$ for citrus flower honey and $14 \mathrm{~mm}$ for eucalyptus honey, this result may be due to the type and natural of the composition of the nectar of flowers and also, the weather conditions where the bees were reared (22).

Table 2. Bacterial isolates sensitivity to some antibiotic (inhibition zone by $\mathrm{mm}$ )

\begin{tabular}{lllll}
\hline Bacterial isolates & \multicolumn{2}{l}{ Natural honey } & \multicolumn{2}{l}{ Commercial honey } \\
\cline { 2 - 5 } & $\begin{array}{l}\text { Citrus flower } \\
\text { honey }\end{array}$ & $\begin{array}{l}\text { Eucalyptus } \\
\text { honey }\end{array}$ & Sinbola honey & Shafi honey \\
\hline E.coli & 20 & 21 & 8 & 0 \\
& $\mathrm{a}$ & $\mathrm{a}$ & $\mathrm{b}$ & $\mathrm{c}$ \\
\hline P.aeruginosa & 19 & 14 & 0 & 0 \\
& $\mathrm{a}$ & $\mathrm{b}$ & $\mathrm{c}$ & $\mathrm{c}$ \\
\hline
\end{tabular}

a, b, c Duncans values Similar letters indicate no significant differences, but different letters indicate significant differences.

Data in table (3) shows the sensitivity of E. coli to the interaction of honey with antibiotics. The table shows that the natural honey of citrus flower is significantly higher than the other types of it followed by eucalyptus honey, the rate of their impact is 25.2 $\mathrm{mm}$ and $24.2 \mathrm{~mm}$ respectively. While, there is no significant difference Between the rate effect for sinbola and shafi honey, and the results show that the Amikacine was the most influential on $E$. coli with an influence rate of $25.25 \mathrm{~mm}$ followed by both the Gentamicin and Chloramphenicol with an influence rate of 23.5 and $23.25 \mathrm{~mm}$ respectively. These result are in agreement with those obtained by Hijwal (23). The effect of interaction between honey and antibiotics show that the treatment citrus flower honey with the amikacine was significantly higher than other treatment with diameter of inhibition $29 \mathrm{~mm}$ followed by the interaction citrus flower honey with the gentamicine with diameter of inhibition $28 \mathrm{~mm}$, then interaction between eucalyptus honey with amikacine with diameter of inhibition $28 \mathrm{~mm}$. The lower diameter of inhibition was recorded of the interaction between sinbola honey with the Ampicillin was $17 \mathrm{~mm}$.

Table 3. Effect of the interaction between honey and antibiotic on inhibition zone $(\mathrm{mm}) \quad$ of E. coli

\begin{tabular}{lllllll}
\hline Honey types & \multicolumn{2}{l}{ antibiotic } & & & \multicolumn{2}{c}{$\begin{array}{c}\text { Rate of honey } \\
\text { effect }\end{array}$} \\
\cline { 2 - 6 } Citrus flower & C & AK & AK & AUG & SAM & 23 \\
& 27 & 29 & 29 & 19 & 23.2 \\
& b & a & a & gh & cd & A \\
\hline Eucalyptus & 27 & 28 & 28 & 18 & 22 & 24.2 \\
& b & ab & ab & hi & de & B \\
\hline Sinbola & 19 & 23 & 23 & 20 & 17 & 19.6 \\
& gh & d & d & gf & i & C \\
\hline Shafi & 20 & 21 & 21 & 20 & 18 & 20 \\
& fg & ef & ef & gf & hi & C \\
\hline Rate of antibiotic effect & 23.25 & 25.25 & 25.25 & 19.25 & $\mathbf{2 0}$ & \\
& B & A & A & D & C & \\
\hline
\end{tabular}

A, B, C Duncans values Similar letters indicate no significant differences, but different letters indicate significant differences. 
Data in table (4) shows the sensitivity of $P$. aeruginosa isolates to honey interaction with antibiotics. The results shows that the natural citrus flower honey a significant superior on other honey types, followed by eucalyptus honey, with an effect rate of 25.2 and $20.2 \mathrm{~mm}$ respectively. The results showed that Amikacine was more inhibited for bacterial growth followed by Gentamicine, with a 30.00 and $26.75 \mathrm{~mm}$ inhibitor rate, respectively. The effect of Interaction between citrus flower honey and amikacine was significantly superior on other interaction treatments with inhibition diameter 36 $\mathrm{mm}$, followed by eucalyptus honey, with Amikacine with inhibition diameter $35 \mathrm{~mm}$, while not giving each of sinbola and shafi honey interaction with Chloramphenicol, Augmenten, and Ampicillin any result, there was no inhibition of bacterial growth.

Table 4. Effect of the interaction between honey and antibiotic on inhibition zone( $\mathrm{mm})$ of $P$. aeruginosa

\begin{tabular}{|c|c|c|c|c|c|c|}
\hline \multirow{2}{*}{ Honey types } & \multicolumn{5}{|c|}{ antibiotic } & \multirow{2}{*}{$\begin{array}{l}\text { Rate of } \\
\text { honey } \\
\text { effect }\end{array}$} \\
\hline & $\mathbf{C}$ & AK & AK & AUG & SAM & \\
\hline \multirow{2}{*}{ Citrus flower } & 18 & 36 & 32 & 20 & 20 & 25.3 \\
\hline & $\mathbf{j}$ & $\mathbf{a}$ & c & $\mathbf{h}$ & h & $\mathbf{A}$ \\
\hline \multirow{2}{*}{ Eucalyptus } & 0 & 35 & 30 & 20 & 19 & 20.8 \\
\hline & $\mathbf{k}$ & $\mathbf{b}$ & d & $\mathbf{h}$ & i & B \\
\hline \multirow{2}{*}{ Sinbola } & 0 & 23 & 22 & $\mathbf{0}$ & $\mathbf{0}$ & 9 \\
\hline & $\mathbf{k}$ & f & $\mathrm{g}$ & $\mathbf{k}$ & $\mathbf{k}$ & D \\
\hline \multirow{2}{*}{ Shafi } & $\mathbf{0}$ & 26 & 23 & $\mathbf{0}$ & 0 & 9.8 \\
\hline & $\mathbf{k}$ & e & f & $\mathbf{k}$ & $\mathbf{k}$ & $\mathrm{C}$ \\
\hline \multirow{2}{*}{ Rate of antibiotic effect } & 4.5 & 30 & 75.26 & 10 & 9.75 & \\
\hline & D & $\mathbf{A}$ & B & $\mathbf{C}$ & $\mathbf{C}$ & \\
\hline
\end{tabular}

A, B, C Duncan values Similar letters indicate no significant differences, but different letters indicate significant differences.

The results of tables (3) and (4) show that honey and antibiotic interaction were increased the efficiency of antibiotic activity by increasing the diameters of bacterial growth inhibition compared with the results in Table (1), As honey possesses inhibitors of bacterial growth, which include hydrogen peroxide and phenolic acids, as well as the osmotic effect of honey caused by sugary component, which causes the breakdown of cellular walls as well as the high honey viscosity, which prevent microbes from penetration and the formation of colonies as well as low acidity of honey ranging from 3.6 to 4.0 (2) and (24). This study confirmed that the use of honey led to increase the efficiency of antibiotics and reduce their dosage and thus reduce the side effects, as we also find from the results that citrus flower honey had the greatest impact on the bacterial isolates followed by eucalyptus and citrus flower honey, while commercial honey was less impact on bacterial isolates.

\section{The References}

1. Vallianou, N.G. ; Gounari, P.; Skourtis,A.; Panagos , J. and Kazazis , C. (2014). Honey and its antiinflammatory, anti- bacterial and antioxidant properties. General Med. 110 - 132.

2. Lu, J. ; Carter,D.A. ; Trunbull , L. ; Rosendale, D. ; Hedderley, D. ; Stephens, J. ; Gannabathula, S. ; Steinhorn , G. Schlothauer, R.C.; Whitchurch , C.B. and Harry, E.J. (2013). The effect of New Zealand kanuka, manuka and clover honeys on bacterial growth dynamics and cellular morphology varies according to the species. PLoS One 8,e55898, doi : 10.1371.

3. Carnwath, R.; Graham, E.M.; Reynolds, K. and Pollock, P.J. (2014). The antimicrobial activity of honey against common equine wound bacterial isolates. Vet.J.199-110.

4. Molan, P. C.; Cooper, R. A.; Tropical Doctor. (2000). Honey and sugar as addressing for wounds and ulcers. American Journal of Clinical Dermatology 30: 249- 250.

5. Kronda, J.M.; Coper, R.A. and Maddocks, S.E. (2013). Manuka honey inhibits siderophore production in pseudomonas aeruginosa. J.Appl. Microbiol.115, 86-90.

6. Campeau, M.E.M. and Patel, R. (2014). Antibiofilm activity of Manuka honey in combination with antibiotics, Hindawi Publishing Corporation Int. J.Bacteriol., 7 Article ID795281.

7. Camplin, A.L. and Sarah, E.M. (2014). Manuka honey treatment of biofilms of pseudomonas aeruginosa results in the emergence of isolates with increased honey resistance. Ann. Clin. Microbiol. Antimicrob,13: 19-28.

8. Roberts, A.E.L. ; Sarah, E.M. and Rose, A.C. (2012). Manuka honey is bactericidal against pseudomonas aeruginosa and result in differential expression of oprF and algD. Microbiolgy, 158: 3005-3013.

9. White , J.W. (1975). Composition of honey. In honey: acomprehensive survey, edited by E. crane. London: Heinemann. 
10. Collee, J.G. ; Faser, A.G. ; Marmion, B.P. and Simmons, A. (1996). Practical Medical Microbiology. $14^{\text {th }}$ ed. Churchill Livingstone.

11. Cappuccino, J.G. and Sherman, N. (1995). Microbiology Lab Manual. USA. BenjaminCummings Publishing Company: 477.

12. Vandeppitt, J.; Engbaek, K.; Piot, P. and Heuch, C.C. (1991). Basik laboratory procedures in clinical Bacteriology. WHO. Geneva , Switzerland.

13. Koneman, W.E. ; Allen, D.S. ; Janda, M.W.; Scherchenberger, C.P. and Winn, W.C. (1992). Color atlas and text book of diagnostic microbiology. $4^{\text {th }}$ edithion. J.B. Lippincott company. Antimicrobial Susceptibility Testing. pp: $624,629,637$.

14. Bauer, A.W.; Kirby, W.M.M. ;Sherirs, J.C. and Turck, M. (1966). Antibiotic susceptibility testing by standard signle disk method.Am.J.Clin.Pathol.45:433-496.

15. SAS. (2005). User Guide. Stastics (Version 6 . 121) SAS . Inst. Cary N.C. U.S.A.

16. Bouhr, D.D. ; Jenkins, S.I. and Wright, G.D. (2003). The moleculer basis of the expansive substrate specificity of the antibiotic resistance enzyme aminoglycoside acetultransferase . J. Bio. Chem. $278: 12873$ - 12880.

17. Levinson, W. and Jaw, E. (2000). A lange medical Book medical microbiology and immunology examination and board review. $6^{\text {th }} \mathrm{ed}$. Mc Grawhill. Pp: 122, 123, 124.

18. Nestor , E.W. ; Anderson , D. G. ; Roberts , C.J. ; Pearsall , N.N. and Nestetr, M.T. (2001).
Microbiology A human perspective". $3^{\text {th }}$ ed. Mc. Fraw-Hill, Higher education, NewYork.

19. Neha Sharma; Sushila Negi; Ajay kumar; Sandip Patil and Amit Kumar. (2012). Comparative Antimicrobial Potential of Raw \& Commercial Hony Against Various Bacteria Isolated From Wound\& Throat Samples. Asian Journal of Biochemical and Pharmaceutical Research.2(2): $31-39$.

20. Al-Nahari, Alaa A.M; Almasaudi, Saad B.; Abd El-Ghany, El Sayed M.; Barbour, Elie; Al Jaouni, Soad K. and Harakeh, steve. (2015). Antimicrobial activity of Saudi honey against pseudomonas aeruginosa.Saudi Journal of Biological Sciences.22, 521-525.

21. Alqurashi, A.M.; Masoud, E.A. and Alamin, M.A. (2013). Antibacterial activity of Saudi honey against Gram negative bacteria. Journal of Microbiology and Antimicrobials . 5(1):1-5.

22. Abd-ElAal, A.M.; El-Hadidy, M.R.; El-Mashad, N.B. and El-Sebaie, A.H. (2007). Antimicrobial effect of bee honey in comparision to antibiotics of organisms isolated from infected burns Ann.Burns Fire Disasters, 20:83-88.

23. Hijwal, S.E. (2013). Effect of Honey on some Biological characters of Klebsiella spp . Anbar Journal of Veterinary Sciences.6(1): 190 - 195.

24. Weston, R. J.; Mitchell, K. R. and Allen, K.L. (1999). Antibacterial phenolic components of New Zealand Manuka honey. Food Chemistry, 64 (3): 295-301. 
مقارنة تأثير العسل الطبيعي والتجاري على نمو بكتريا Escherichia coli و الجي وحساسيتهما للمضادات الحيوية

شيماء عبد محمد علي

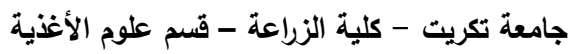

Sheimaa.abed@yahoo.com

: الملخص : n

أجريت هذه الدراسة لتقييم الفعالية التثبيطية لنوعين من العسل الطبيعي ( عسل القداح وعسل اليوكالبتوس) ونوعين من العسل التجاري

المنوفر في الأسواق (عسل السنبلة وعسل الثافي) في نمو العزلات البكتيرية Aseudomonas aeruginosa , Escherichia coli

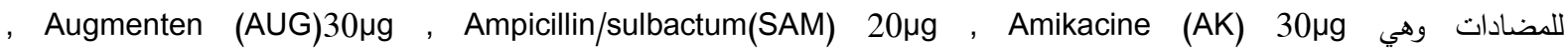

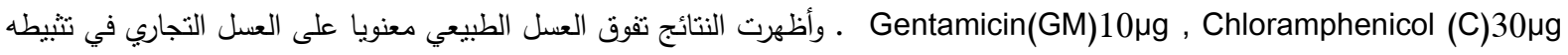
19 P. aeruginosa للنمو البكتبري لجميع العزلات اذ بلغ قطر تثبيط عسل القداح وعسل اليوكالبتوس لنمو

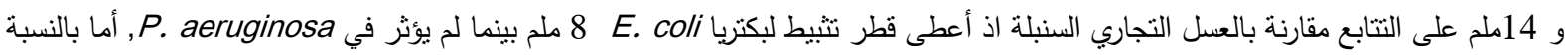
لعسل الثافي فلم يظهر أي تأثير على نمو العزلات البكتيرية. كذلك أظهرت النتائج تفوق عسل القداح معنويا على عسل اليوكالبتوس , اذ بلغ قطر تثبيط عسل القداح لبكتريا P. aeruginosa 19 ملم مقارنة بعسل اليوكالبتوس والذي بلغ 14 ملم. كما أظهرت النتائج أيضا بأن التأثثر التثبيطي بلغي

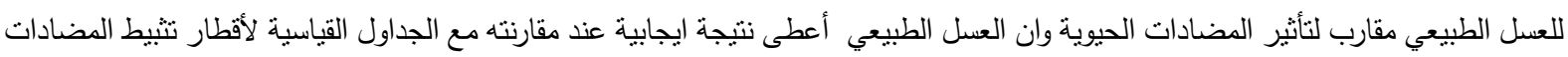

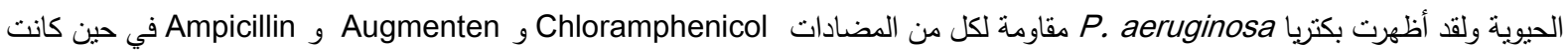

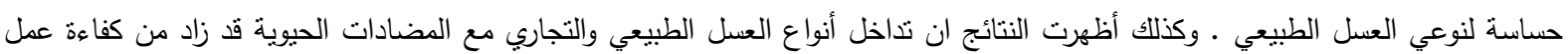
المضادات من خلا زيادة أقطار التثبط للنمو البكتيري اذا ما قورنت مع أقطار التثبط التي اعطتها المضادات الحيوية وقد كان لعسل القداح التأثير

التثبطي الأكبر في العزلات البكتيرية عند تداخله مع المضادات الحيوية يليه عسل اليوكالبتوس بينما كان عسل السنبلة التجاري الأقل تأثيرا .

Pseudomonas aeruginosa ، Escherichia coli , الكلمات المفتاحية : العسل ، المضادات الحيوية العية 